\title{
Research into Diversified Construction of College Students' Innovation Practical Projects in Independent Colleges
}

\author{
Xiaojun Wang and Yongjian Huang \\ Polytechnic Institute of Jiangxi Science and Technology Normal University
}

Keywords: Independent college; Diversification; Innovative practices; College student.

\begin{abstract}
College students are the backbone of the current and future social development, so it is the bounden duty of colleges and universities to cultivate college students' innovation spirit and innovation capacity. As an important part of colleges and universities, independent colleges bear the responsibility and task of cultivating application-oriented talents for higher education, so it is particularly important to research how to improve the innovative practical ability of students at independent colleges so as to better cultivate application-oriented innovation talents.
\end{abstract}

\section{Introduction}

China is transiting from a "made-in-China" giant into a "intelligence-of-China" power, so it is not only the demand of time but also a necessary means of implementing the strategy of empowering China with talents to cultivate a huge amount of innovative talents, and there should be more technical and application-oriented innovative talents in China. Independent colleges shoulder the historical responsibility of cultivating technical and application-oriented talents, and the innovation capacity of students from independent colleges is directly related to the level of innovation in the field of application technology in China. In order to change the current situation that Chinese students have strong ability of taking exams but poor innovation ability, it is necessary to research into a scientific, reasonable and feasible method to evaluate independent college students' innovation ability and give full play to innovation ability's guiding, orientating and motivation functions while cultivating independent college students' innovation spirit so as to improve independent college students' innovation ability.

In order to cultivate college students' practical and innovation ability, it is also necessary to establish a reasonable motivation mechanism and adopt various specific and effective measures to encourage college students to conduct scientific researches, stimulate their desire to innovate and tap their potential of innovation. According to their own situation and based on practice, colleges abilities, such as science and technology competition, entrepreneurship contest, design contest and writing innovative academic theses, etc., guide students to get involved in practical activities such as visiting, investigation and social investigation, set innovation scholarship and credits and give suitable materials rewards to college students with innovation results. Meanwhile, they should give priority to these factors while choosing recommended graduates so as to stimulate students' enthusiasm and expectation for innovation.

Current Situation of Conducting Innovative Practices among Independent College Students. College students' practical innovation projects are an important carrier for schools to conduct scientific and technological innovation activities while playing a key role in cultivating application-oriented talents with scientific consciousness, innovation spirit and practical ability. During the process of carrying out college students' practical innovation activities, more and more colleges and universities adopt the project innovation mode to guide innovation practices and actively internalize the projects according to their actual condition so as to improve teachers and students' enthusiasm and initiative in participating innovation projects as well as the operation effect of the overall project.

Independent Colleges because of their special nature, not enough attention to the intensity of school, students' overall active thinking, but the lack of toughness, overall school climate research and innovation is not strong, innovative practice settings are more single project, the objective limits to carry out innovative practice activities. But we cannot deny the independent college 
student population, there are a lot of motivated young people who have a strong motivation and learning momentum, but hope that their efforts and achievements recognized by others, in the hope that innovative practice Students to carry out projects to achieve good results. Independent Colleges and thus no lack of innovative practice and soil factors, the key to how school science organization and implementation, in order to fully mobilize the enthusiasm and initiative of teachers and students, formed the courage to innovate, to innovate, and to love the atmosphere of innovation.

\section{Significance of Conducting College Students' Practical Innovation Activities}

College students are the successors of China's future construction, so they cannot just be useless furnishings. Therefore, it is the demonstration of meeting the society's demand for innovative talents to enhance practical education, cultivate college innovation ability and practical spirit.

Innovation is the theme of the current world - the knowledge innovation, technological innovation, industrial innovation accelerating, based on economic, science and technology, cultural soft power is a concentrated expression of the increasingly fierce competition in overall national strength. Wealthy and strong country is the common wish of every Chinese people, but also to achieve the great rejuvenation of Chinese nation, "China Dream" an important part. Institutions of higher learning as the culture of the motherland to build the future successor to the cradle shoulder "scholarly self, and the world economy," the ideal and mission, how to deal with the new demands of social and economic development of talents strategy, so cultivating innovative talents is an urgent issue.

At the same time, strengthening the practice of teaching students, but also innovation talent strategy, implementation requires talent development. Xi Jinping attended the Academy of Sciences, Chinese Academy of Seventeenth General Assembly, when the Chinese Academy of engineering academician Twelfth General Assembly noted that innovation calls for innovative business talent. To achieve the great rejuvenation of the Chinese nation, the better talent, skill better. Knowledge is power, and talent is the future. China should go in technological innovation in the world, must find talent in innovation practice and nurture talent in innovation activities, the talent pool in the innovation business; we must vigorously cultivate large-scale, reasonable structure, excellent quality and innovative talents.

\section{Diversified Innovation Practice and Teaching Innovation}

Teaching Students in Accordance to Three Aptitudes and Own Characteristics. Given the independent college students own foundations uneven, using the principle of individualized teaching. College students are mainly taken at different levels of education. The so-called sub-level education students according to their future university plans to select the direction of the study. Education-oriented one: choose a deep direction of a solid foundation of theoretical knowledge and test capability, ready to accept further master's, doctoral degree education; education guide 2: Select control direction of employment of skilled employment skills and excellent workplace literacy; education guide three: choose a good foundation and foreign language speaking ability, good comprehensive quality, able to adapt to the development direction of study abroad.

Strengthening Construction of Teaching Team to Realize the Goal of Cultivating Talents. Establishing a team of stable and excellent teaching staff is the powerful guarantee for healthy development of a college. Most full-time teachers recruited by a college have a Master's degree or above, and some have a Doctor's degree with rich teaching experience. Also, some teachers are professional technicians from enterprises or corporates with rich practical experience. Besides, colleges also hire well-known professors and experts to form a stable team of high-quality teaching staffs.

Reform Teaching Mode and Teaching Method to Meet Students' Development. The traditional teaching model has not adapted to the culture of diverse talents, instead it is interactive classroom teaching. Class, teachers use a variety of modes of teaching methods, in addition to teaching textbook knowledge to the students to increase self-learning space and time, through 
discussion groups and other forms, focusing on students' interest in learning, attention to guide students to learn. Teachers from the individual differences of students starting to arrange the teaching content to observe the students 'learning trends from multiple perspectives, master students' knowledge of understanding, and guide students to use the most suitable learning methods to learn and adjust teaching ideas and methods to make Teaching significantly better.

\section{Conclusion}

Construction in Independent College Students carries out practical activities in innovation, innovative practice diversified construction projects Students' creative and practical ability of a proposed useful ide. School Practice project to create innovative systems based on different channels to provide different innovative projects in accordance with the practice of student grades, levels and the ability to expand the coverage of innovative practice, and enhance independent college students' sense of innovation and creativity. In short, with the development of society, to establish independent college training model for their own development of the Institute, education and innovation, strengthening the quality of teaching, improvise the education system can be healthy and sustainable development.

\section{References}

[1] Jing H E. Analysis and Measures on the Independent Enrollment Students in Higher Vocational Colleges_—_To Take Guangzhou Panyu Polytechnic for an Example[J]. Journal of Guangzhou Panyu Polytechnic, 2011.

[2] Wang F. The Dilemma of Institutionalization of Independent College Policy Change Shaped by Multiple Institutional Logics [J]. Peking University Education Review, 2012.

[3] Guo G, Huang J, Ying M. The Configuration and Exploration of Cultivating Market-oriented Practical Talents in Independent College [J]. Journal of Xidian University, 2008.

[4] Ling L I, Institute C. On the Diversified Talents Cultivation Mode of Independent College [J]. Value Engineering, 2015.

[5] Liu J L. The employment and employment innovation practice in independent college [J]. Journal of Jiamusi Education Institute, 2011.

[6] Washback effect of compound- dictation in CET-4 on Independent College [J]. Beijing Dianli,Gaodeng,Zhuanke Xuexiao Xuebao, 2012(9).

[7] Yutao H U, Xinyan M A, Marxism S O, et al. On the Effectiveness of Ideological and Political Theory Course of Independent College Cultural Diversity [J]. Journal of Sichuan Vocational \& Technical College, 2014.

[8] eodoros D. A new era in speech-language pathology practice: innovation and diversification.[J]. International journal of speech-language pathology, 2012, 14(3):189-199.

[9] Mishina Y, Pollock T G, Porac J F. Are more resources always better for growth? Resource stickiness in market and product expansion [J]. Strategic Management Journal, 2004, 25(12):1179-1197.

[10]Xie Aijuan, Zhang Baoling, Meng Qi, et al. Practice and Innovation of an Experimental Teaching Mode in Independent College Based on Cloud Computing [J]. Higher Education in Chemical Engineering, 2014.

[11]Hall D M, Stevenson H C. Double Jeopardy: Being African-American and "Doing Diversity" in Independent Schools.[J]. Teachers College Record, 2007, 109(1):1-23.

[12] Mfuni T. Baruch College continues to fail diversity [J]. New York Amsterdam News, 2006. 